\title{
TOTOBUANG
}

Volume $5 \quad$ Nomor 2, Desember $2017 \quad$ Halaman 199-213

\section{MENINGKATKAN KEMAMPUAN SISWA MENULIS PUISI \\ DENGAN MENGGUNAKAN MEDIA GAMBAR \\ (Improving Students 'Capabilities in Writing Poetry Using Images Media)}

\author{
Sakila \\ SMP Negeri 2 Singkawang \\ Jalan Pahlawan, Kota Singkawang, Indonesia \\ Pos-el: sakilaspd@yahoo.co.id
}

(Diterima: 31 Oktober 2017; Direvisi 13 November 2017; Disetujui: 29 Desember 2017)

\begin{abstract}
The purpose of this study was improving the process of learning to write poetry of the students of class VII C SMP Negeri 2 Singkawang in academic year 2016/2017. This research was conducted using classroom action research through 2 cycles, each cycle consists of four stages of planning, actuating, observation, and reflection. Data sources were obtained from learning activities, information from Indonesian language teachers and documents. Data collection used observation, interviews and tests. The research instrument was applied to measure the skill of writing poetry of the students which consisted of the unity of the dictionand the theme, event and the lines of poetry. The conclusion of this research showed that the use of image media in learning to write poetry of students of class VII C SMPN 2 Singkawang was able to improve students' ability in learning of writing poetry. This could be seen from the increasement of predetermined indicators. Percentage of attention and concentration of students during apperception andlearning writing poetry had increased significantly at the time. Keywords: student ability, poetry writing, picture media
\end{abstract}

Tujuan penelitian ini adalah untuk meningkatkan proses pembelajaran menulis puisi pada siswa kelas VII C SMP Negeri 2 Singkawang tahun ajaran 2016/2017. Penelitian ini menggunakan penelitian tindakan kelas yang dilaksanakan melalui 2 siklus, masing-masing siklus terdiri dari 4 tahap yaitu perencanaan, pelaksanaan, observasi dan refleksi. Sumber data diperoleh dari kegiatan pembelajaran, informasi dari gur Bahasa Indonesia dan dokumen. Pengumpulan data menggunakan observasi, wawancara dan tes. Instrumen penelitian yang digunakan bertujuan untuk mengukur keterampilan menulis puisi pada siswa terdiri dari aspek kesatuan pilihan kata dengan tema, peristiwa dan larik-larik puisi. Berdasarkan hasil penelitian diperoleh kesimpulan bahwa penggunaan media gambar dalam pembelajaran menulis puisi pada siswa kelas VII C SMPN 2 Singkawang mampu meningkatkan kemampuan siswa dalam pembelajaran menulis puisi. Hal ini dapat diketahui dari adanya peningkatan indikator-indikator yang telah ditetapkan. Persentase perhatian dan konsentrasi siswa selama apersepsi dan pada saat pembelajaran menulis puisi mengalami peningkatan yang cukup signifikan.

Kata-kata kunci: kemampuan siswa, menulis puisi, media gambar.

\section{PENDAHULUAN}

Berdasarkan

Peraturan Menteri Pendidikan Nasional Nomor 22 Tahun 2006 tanggal 23 Mei 2006 disebutkan bahwa pendidikan nasional yang berdasarkan Pancasila dan UUD Negara Republik Indonesia 1945 berfungsi mengembangkan kemampuan dan membentuk watak serta peradaban bangsa yang bermartabat dalam rangka mencerdaskan kehidupan bangsa, bertujuan untuk mengembangkan potensi peserta didik agar menjadi manusia yang beriman dan bertakwa kepada Tuhan Yang Maha Esa, berakhlak mulia, sehat, berilmu, cakap kreatif, mandiri dan menjadi warga negara yang demokratis serta bertanggungjawab.

Peningkatan mutu pendidikan diarahkan untuk meningkatkan kualitas manusia Indonesia seutuhnya melalui olah hati, olah pikir, olah rasa dan olahraga agar memiliki daya saing dalam menghadapi 
tantangan global. Dalam Kurikulum Tingkat Satuan Pendidikan (KTSP) mata pelajaran Bahasa dan Sastra Indonesia SMP/MTs kelas VII salah satu standar kompetensi keterampilan menulis adalah mengungkapkan perasaan dalam puisi bebas. Sementara itu kompetensi dasarnya adalah menulis puisi bebas dengan menggunakan pilihan kata yang sesuai.

Menulis seperti halnya kegiatan berbahasa lainnya, merupakan keterampilan. Setiap keterampilan hanya akan diperoleh melalui latihan. Berlatih secara sistematis, terus-menerus, dan penuh disiplin merupakan resep yang selalu disarankan oleh praktisi untuk dapat atau terampil menulis. Tentu saja bekal untuk berlatih bukan hanya sekedar kemauan, akan tetapi juga ada bekal lain yang perlu dimiliki. Bekal lain itu adalah pengetahuan, konsep, prinsip, dan prosedur yang harus ditempuh dalam kegiatan menulis. Jadi ada dua hal yang diperlukan untuk mencapai ketrampilan menulis yakni pengetahuan tentang tulis menulis dan berlatih untuk menulis (Syarif, 2009:1)

Menulis puisi merupakan salah satu keterampilan berbahasa yang harus dimiliki siswa SMP/MTs. Pembelajaran menulis puisi merupakan kompetensi dasar yang harus dimiliki oleh siswa kelas VII namun kenyataan di lapangan masih banyak siswa yang belum mampu menulis puisi. Ketidakmampuan siswa dalam menulis puisi disebabkan karena mengalami kesulitan dalam menulis puisi. Mereka kurang memiliki minat untuk membaca, siswa tidak tertarik dalam pelajaran Bahasa Indonesia khususnya menulis puisi karena cara penyampaian guru yang kurang menarik dan proses pembelajarannya monoton.

Siswa yang ingin terampil menulis tidak cukup dengan mempelajari bahasa dan kemapuan tentang teori menulis, karena keterampilan menulis merupakan suatu proses pertumbuhan melalui banyak praktik dan latihan yang teratur. Oleh karena itu, pembelajaran dalam bidang tulis menulis sangat diperlukan (Suryana, 2013). Namun kenyataannya, belum banyak siswa yang memiliki keterampilan dimaksud. Ada anggapan bahwa menulis puisi adalah pekerjaan penyair atau sastrawan. Jadi hanya yang memiliki bakatlah yang bisa menulis puisi. Sebagian orang berasumsi demikian, namun menulis puisi perlu latihan dan pengajaran bukan semata-mata bawaan sejak lahir.

Beberapa permasalahan yang penulis temukan dalam pembelajaran di kelas adalah terdapat beberapa siswa yang merasa kesulitan dalam menulis puisi. Hal ini disebabkan karena siswa kurang berpengalaman, kurang memiliki minat untuk membaca sehingga daya imajinasinya menjadi berkurang.

Selain itu, kelemahan lain terletak pada cara, metode, atau media yang digunakan guru dalam proses pembelajaran masih kurang maksimal. Berhasil tidaknya pembelajaran bahasa Indonesia khususnya untuk mencapai keberhasilan pelajaran menulis ditunjang beberapa faktor yang saling berkaitan, yaitu metode, teknik, dan media pembelajaran yang digunakan.

Penggunaan media pembelajaran sangat diperlukan dalam kaitannya dengan peningkatan mutu pendidikan khususnya dalam pelajaran menulis puisi karena media pembelajaran digunakan dalam upaya meningkatkan atau mempertinggi mutu proses kegiatan belajar mengajar. Hal ini sejalan dengan pendapat Suyatno (2004:147) yang mengatakan bahwa digunakannya media gambar bertujuan agar siswa dapat membuat puisi dengan cepat dan benar berdasarkan gambar yang dipilihnya. Berdasarkan pada pendapat tersebut, media gambar merupakan salah satu alternatif yang memudahkan siswa dalam menulis puisi. Dengan menggunakan media gambar dalam proses pembelajaran itu, diharapkan siswa merasa senang dan tertarik untuk mempelajarinya. Selanjutnya ditambah lagi guru sudah menyediakan gambar sehingga imajinasi siswa berkembang, walaupun 
ketika menuliskan apersepsi melalui gambar ke dalam karya tulisnya masih sangat kurang. Menulis merupakan kegiatan melahirkan pikiran dan perasaan. Puisi yang dihasilkan biasanya merupakan ekspresi dari hati. Puisi merupakan salah satu bentuk karya sastra. (Setiyaningsih, 2015:12). Sebagai suatu keterampilan, menulis memang harus melalui proses belajar dan berlatih. Semakin sering belajar dan berlatih, tentu siswa akan semakin cepat terampil. Seseorang yang sudah biasa menuliskan sebuah ide, gagasan, pendapat, atau perasaannya, dia tidak akan mengalami kesulitan yang berarti ketika harus menulis. Berbeda halnya jika seseorang jarang atau bahkan sama sekali tidak pernah membuat sebuah karya tulis. Tentunya orang tersebut akan mengalami banyak kesulitan ketika diminta menuliskan sesuatu. (Maharani, 2012: 1-2)

Ada beberapa penelitian terdahulu yang relevan dengan penelitian ini dan dapat dijadikan sebagai tinjauan pustaka, diantaranya adalah Yuliyanto (2009) melakukan penelitian tindakan kelas mengenai penggunaan media gambar dalam pembelajaran menulis puisi dengan judul Peningkatan Kemampuan Menulis Puisi dengan Media Gambar Karikatur melalui Teknik Pancingan Kata Kunci Siswa Kelas VIII F SMP Negeri 13 Semarang Tahun Pelajaran 2008/2009. Simpulan penelitian ini adalah keterampilan menulis puisi siswa kelas VIII F SMP Negeri 13 Semarang meningkat setelah dilaksanakan pembelajaran dengan menggunakan media gambar karikatur melalui teknik pancingan kata kunci dan hasilnya terjadi perubahan perilaku siswa ke arah positif. Keterkaitan penelitian tersebut dengan penelitian yang dilakukan adalah sama-sama meneliti keterampilan menulis puisi. Hanya saja penggunaan media pembelajaran yang digunakan peneliti lebih spesifik, yaitu media gambar pemandangan alam.

Berdasarkan permasalahan tersebut, penulis tertarik untuk meneliti kegiatan pembelajaran dengan menggunakan media yang murah dan mudah didapat yaitu media gambar. Dengan demikian penelitian ini diberi judul "Peningkatan Keterampilan Menulis Puisi Dengan Media Gambar Pada Siswa Kelas 7C'. Berdasarkan latar belakang masalah yang telah disebutkan, masalah dalam penelitian ini adalah bagaimana menerapkan media gambar dalam meningkatkan keterampilan siswa dalam menulis puisi?

Tujuan penulisan laporan penelitian ini adalah untuk menyampaikan hasil penerapan media gambar dalam meningkatkan hasil belajar dalam menulis puisi pada siswa SMP pada kelas 7C. Adapun manfaat penelitian ini sebagai berikut:

1) Bagi guru

Dengan dilaksanakannya penelitian ini, guru memiliki kemampuan untuk menggunakan media gambar dalam menulis puisi. Guru dapat meningkatkan kualitas pembe-lajarannya yang sangat berpusat pada siswa.

2) Bagi siswa

Penulisan penelitian ini akan bermanfaat bagi siswa untuk meningkatkan kemampuannya dalam menulis puisi, bukan suatu hal yang mem-bosankan, melainkan merupakan sesuatu yang sangat menyenangkan.

3) Bagi sekolah

Bagi sekolah penelitian ini akan memberikan sumbangan yang baik pada sekolah dalam rangka perbaikan pembelajaran pada khususnya dan sekolah pada umumnya.

\section{LANDASAN TEORI \\ Keterampilan Menulis Puisi}

Menurut Depdiknas (2005:54) ada beberapa kegiatan penunjang untuk meningkatkan kreativitas dalam penulisan puisi: Pertama, membaca, membaca, menulis dan menulis. Seorang penyair dan pengarang pemula harus tidak henti-hentinya melakukan kegiatan membaca dan menulis. Kedua, aktif berdiskusi tentang karya sastra. Seorang 
penyair dan pengarang pemula sebaiknya aktif menyampaikan pendapat dan pandangan dalam diskusi-diskusi sastra baik yang diadakan di sekolah maupun di luar sekolah. Ketiga, aktif mendokumentasikan karya sendiri maupun karya-karya penyair lain. Kegiatan ini secara tidak langsung dapat menunjang ketajaman dalam berimajinasi, sebab seorang doku-mentator pasti membaca terlebih dahulu karya-karya yang didokumen-tasikan. Keempat, mendekatkan diri pada sang Khalik. Dengan Selalu mendekatkan diri kepada Tuhan Yang Maha Kuasa seorang penyair dan pengarang pemula akan memperoleh penga-laman batiniah.

Ada anggapan sebagian orang bahwa menulis puisi itu sebagai bakat yang dibawa sejak lahir, sehingga tidak setiap orang dapat menulis puisi. Hal ini sebagaimana yang dikemukakan oleh Wiyanto dalam Sudibyo (2008:2) bahwa kemampuan menulis puisi sering dianggap sebagai bakat sehingga orang yang merasa tidak mempunyai bakat tidak akan dapat menulis, akan tetapi bakat tidak berarti tanpa ada pelatihan. Tanpa bakat bila seseorang rajin belajar dan giat berlatih, ia akan terampil dalam menulis puisi. Berdasarkan pendapat tersebut, menulis puisi termasuk jenis keterampilan, seperti halnya jenis keterampilan lainnya, pemerolehannya harus melalui belajar dan berlatih, semakin sering belajar dan semakin giat berlatih, tentu semakin cepat terampil.

Puisi adalah sebuah karya yang lahir dari hati. Oleh karena itu kegiatan menulis puisi merupakan hal yang sangat pribadi dan termasuk salah satu jenis tulisan pribadi. Hal ini sebagaimana yang dikemukakan Tarigan (2008: 31) bahwa tulisan pribadi adalah suatu pernyataan dari gagasangagasan serta perasaan-perasaan kita mengenai pengalaman kita yang ditulis, bagi kesenangan kita sendiri, maupun bagi kepentingan dan kenikmatan sanak keluarga dan sahabat karib. Bentuk-bentuk tulisan pribadi ini antara lain sebagai berikut: (1) buku harian; (2) catatan harian, jurnal; (3) cerita tidak resmi; (4) surat; dan (5) puisi.

Adapun teknik-teknik penu-lisan puisi menurut Depdiknas (2005:34-39) adalah sebagai berikut (a) bahan puisi. Dari mana memulai penulisan puisi? Tentu saja dari bahan. Banyak teori menyebutkan bahwa menulis puisi itu bermula dari tema karena tema merupakan hal yang hendak dikatakan penyair; (b) bentuk ekspresi. Bentuk ekspresi menyangkut ciri visual puisi. Bagaimana kita menulis puisi, dalam arti menata hurufnya secara grafis. Puisi secara visual dibentuk oleh larik dan bait. Pada umumnya satu bait mengandung satu pokok pikiran. Fungsi bait tak jauh berbeda dengan fungsi paragraph dalam karya paparan. Satu bait dapat terdiri atas satu larik atau lebih; (c) Pengembangan bahan. Dalam proses penciptaan puisi terdapat pelbagai sikap penyair dalam menghadapi realitas sebagai bahan; pertama, penyair sebatas merekam peristiwa atau fenomena alam; kedua, penyair memakai realitas sebagai media untuk mengungkapkan gagasan atau perasaan tertentu; ketiga gagasan diungkapkan oleh penyair secara terbuka, dan keempat, gagasan atau realitas diungkapkan dengan mendayagunakan potensi bahasa yang unik dan menarik.

Adapun langkah-langkah menulis puisi sebagaimana yang dikemukakan Setiyaningsih (2015:12) bahwa ketika menulis puisi, langkah-langkahnya sebagai berikut: (1) Menentukan tema puisi; (2) Menuliskan apa yang ada dalam hati sejelas mungkin sesuai dengan tema yang dipilih; (3) Mengembangkan pilihan kata yang sudah dipilih ke dalam larik-larik beraturan; (4) Menyusun larik-larik puisi menjadi bait dengan memperhatikan rima atau persamaan bunyi; (5) Memberi judul puisi yang dibuat. Selanjutnya menurut Suyatno (2004:147) langkah-langkah pelak-sanaan menulis puisi adalah sebagai berikut (1) Guru memberikan pen-jelasan singkat tentang kegiatan hari itu; (2) Siswa menerima gambar dari guru; (3) Siswa mengidentifikasi gambar tersebut; (4) Siswa menulis puisi berdasarkan 
hasil identifikasi yang dibuatnya; (5) Siswa lain memberikan komentar dan penilaian tentang isi puisi itu; dan (6) Guru merefleksi hasil pembelajaran hari itu.

Indikator keberhasilan pelak-sanaan pembelajaran menulis puisi difokuskan pada dua aspek, yaitu aspek proses dan aspek hasil. Aspek proses ditujukan pada aktivitas proses pembelajaran yang dilakukan siswa dan guru. Pada aspek proses hal yang diperhatikan adalah keaktifan, kerjasama, dan kreativitas. Penentuan pada aspek hasil ditekankan pada hasil yang diperoleh siswa dalam menulis puisi, penilaiannya meliputi empat komponen, yaitu isi, tipografi, pengimajinasian dan keontetikan, (Prasetyo, 2007: 60)

\section{Media Gambar}

Penggunaan media yang sesuai akan memberikan manfaat yang sangat besar bagi keberhasilan proses belajar mengajar. Hal ini sejalan dengan pendapat Sudjana dan Rivai (2007:2) bahwa media pembelajaran dapat mempertinggi proses belajar siswa dalam pengajaran yang pada gilirannya diharapkan dapat mempertinggi hasil belajar yang dicapainya. Secara lebih khusus, pengertian media adalah dalam proses belajar mengajar cenderung diartikan sebagai alat-alat, grafis, photografis atau elektroniks untuk menangkap, memproses dan menyusun kembali informasi visual maupun verbal (Alamsyah, 2015).

Selanjutnya Gagne dan Briggs dalam Arsyad (2007:4) secara implisit menyatakan bahwa media pembelajaran meliputi alat yang secara fisik digunakan untuk menyampaikan isi materi pengajaran yang terdiri dari antara lain buku, tape recorder, kaset, video kamera, film, slide, (gambar bingkai), foto, gambar, grafik, televisi dan komputer. Dengan kata lain media adalah komponen sumber belajar atau wahana fisik yang mengandung materi instruksional di lingkungan siswa yang dapat merangsang siswa untuk belajar.

Begitu juga dengan pendapat
Sadiman dkk, (2011: 28-29) bahwa media gambar sebagaimana halnya media yang lain. Media untuk menyalurkan pesan dari sumber ke penerima pesan. Saluran yang dipakai menyangkut indera penglihatan. Pesan yang akan disampikan dituangkan ke dalam simbol-simbol komunikasi visual. Simbolsimbol tersebut perlu dipahami benar artinya agar proses penyampian pesan dapat berhasil dan efisien.

Diantara media pembelajaran yang ada, media gambar adalah media yang paling umum dipakai. Hal ini dikarenakan siswa lebih menyukai gambar daripada tulisan, apalagi jika gambar dibuat dan disajikan sesuai dengan persyaratan yang baik, sudah tentu akan menambah semangat siswa dalam mengikuti proses pem-belajaran. Media gambar lebih mudah dimengerti dan dapat dinikmati, mudah didapatkan dan dijumpai, serta banyak memberikan penjelasan bila dibandingkan dengan bahasa verbal (kata-kata). Sanaky (2009: 69) mengemukakan adanya perbedaan antara media gambar atau foto dengan verbal, antara lain sebagai berikut: (1) media gambar atau foto, memvisualkan apa adanya secara detail, (2) verbal (kata-kata), kelemahannya terletak pada keterbatasan daya ingat dalam bercerita dan menjelaskan, sehingga mungkin ada halhal yang tercecer atau terlupakan dalam menyampaikan pesan.

Sebagaimana diketahui bahwa media pembelajaran adalah sarana pembelajaran yang digunakan siswa atau guru untuk proses belajar mengajar. Media yang dapat digunakan dalam pembelajaran pengembangan penulisan puisi menurut Depdiknas (2005: 75) yaitu papan tulis (white board) buku puisi, foto, proses kreatif penyair dan lain sebagainya. Selanjutnya metode pembelajaran dalam penulisan puisi beserta berbagai medianya. Tahap pertama, mengamati keindahan alam dalam kelompok kecil; Tahap kedua, menyelenggarakan perlombaan antar kelompok kecil di tingkat kelas; Tahap ketiga, pengenalan figur dan magang; Tahap keempat, mempublikasikan 
puisi yang diciptakan siswa, dan Tahap kelima, mengadakan wisata sastra.

Salah satu media yang akan digunakan dalam pembelajaran penulisan puisi adalah media gambar (foto). Media gambar ini merupakan media visual. Menurut Suyatno (2004:147) menyatakan "Media gambar bertujuan agar siswa dapat menulis puisi dengan cepat dan benar berdasarkan gambar yang dilihatnya." Selanjutnya dikemukakan pula Suyatno (2004:147) "Siswa melihat gambar yang diberikan oleh guru dari melihat itu siswa menulis puisi." Alat yang diperlukan adalah bermacammacam gambar atau poster.

Berdasarkan hal tersebut, yang dimaksud media gambar dalam penelitian ini adalah salah satu alternatif untuk memudahkan dan menunjang siswa dalam menulis puisi.

Selanjutnya dengan perlakuan ini siswa akan merasa senang dan mudah karena adanya kemampuan imajinatif yang baru setelah melihat media gambar.

Media Gambar dimanfaatkan oleh guru dalam pembelajaran agar materi dapat dengan mudah diterima siswa. Menurut Sadiman ( 2001: 36) bahwa setiap gambar harus mempunyai tujuan tertentu sesuai dengan tujuan pembelajaran yang ingin dicapai. Jumlah gambar yang akan diperlihatkan kepada siswa harus dibatasi yaitu dengan memperhatikan satu persatu sesuai dengan materi yang diajarkan.

\section{Kelebihan dan Kekurangan Media Gambar}

Penggunaan media gambar dalam pembelajaran, tentunya memiliki kelebihan dan kekurangan masing-masing. Adapun kelebihan dan kekurangannya disampaikan oleh beberapa pendapat. Kelebihan media gambar ini diungkapkan oleh Sadiman (2001:31)

1) Sifat konkret;

2) Dapat mengatasi batasan ruang dan waktu;

3) Media gambar Dapat mengatasi keterbatasan pengamatan;
4) Dapat Memperjelas suatu masalah;

5) murah harganya dan gampang didapat serta digunakan tanpa memerlukan peralatan khusus;

Adapun Kelebihan media gambar menurut Daryanto (2011:100) adalah sebagai berikut:

1) Mudah dimanfaatkan di dalam kegiatan belajar mengajar karena praktis tanpa memerlukan perlengkapan apa-apa;

2) Harganya relatif murah dari pada jenisjenis media pengajaran lainnya;

3) Gambar dapat dipergunakan dalam banyak hal, untuk berbagai jenjang pengajaran dan berbagai disiplin ilmu;

4) Gambar dapat menerjemahkan konsep atau gagasan yang abstrak menjadi realistik;

Adapun kelemahan media gambar:

1) Hanya menampilkan persepsi indera mata, ukurannya terbatas hanya dapat terlihat oleh sekelompok siswa;

2) Gambar diinterprestasikan secara personal dan subyektif;

3) Gambar disajkan dalam ukuran yang sangat kecil, sehingga kurang efektif dalam pembelajaran (Rahadi, 2003:27)

Sedangkan kekurangan media gambar menurut Daryanto (2011:101) antara lain:

1) Beberapa gambarnya sudah cukup memadai tetapi tidak cukup besar ukurannya jika digunakan untuk tujuan pengajaran kelompok besar, kecuali jika diproyeksikan melalui projector;

2) Gambar adalah berdimensi dua sehingga sukar untuk melukiskan bentuk sebenarnya yang berdimensi tiga;

3) Gambar tetap tidak memperlihatkan gerak seperti halnya gambar hidup.

\section{METODE}

Penelitian ini dilaksanakan di SMP Negeri 2 Singkawang, pada tahun ajaran 2016/2017 dimulai pada Februari sampai dengan Maret 2017. Jumlah siswa kelas $7 \mathrm{C}$ adalah 34 orang. Faktor yang diteliti dalam penelitian tindakan kelas ini adalah sebagai berikut: Faktor siswa, kemampuan menulis surat pembaca tentang lingkungan sekolah. Di 
samping itu kepekaannya dan sikapnya terhadap kemampuan menulis surat pembaca khususnya dan sastra pada umumnya. Faktor guru, cara guru merencanaan pembelajaran serta bagaimana pelaksanaannya di kelas. Penelitian ini menggunakan pendekatan paradigma kualitatif, berangkat dari permasalahan pembelajaran di kelas, ditindak lanjuti dengan penerapan suatu tindakan pembelajaran kemudian direfleksi, dianalisis dan dilakukan penerapan kembali pada siklus berikutnya, setelah dilaksanakan revisi berdasarkan temuan saat refleksi. Sedangkan dilihat dari tujuannya, penelitian termasuk penelitian tindakan, yaitu menerapkan suatu tindakan perbaikan untuk mengatasi masalah yang ditemukan. Karena penelitian dilaksanakan dengan setting kelas, maka disebut penelitian tindakan kelas (PTK) yang memberikan kesempatan kepada guru mengor-ganisasikan kondisi praktek pembelajaran dan belajar dari pengalaman itu menemukan gagasan perbaikan serta melihat pengaruh dan hasilnya dalam praktek pembelajaran (Wiriaatmadja 2005:13). PTK ini menggunakan model Stephen Kemmis dan Mc Taggart (dalam Sukidin, 2002:49), sistem spiral refleksi diri yang dimulai dari rencana, tindakan, pengamatan, refleksi, dan perencanaan kembali yang merupakan dasar untuk suatu rancangan pemecahan masalah. Menurut Arikunto (2006: 3) penelitian tindakan kelas merupakan suatu pencermatan terhadap kegiatan belajar berupa sebuah tindakan yang sengaja dimunculkan dan terjadi dalam sebuah kelas secara bersama. Selain pengertian tadi, penelitian tindakan kelas dapat diartikan sebagai sebuah penelitian yang menuntut kerjasama peneliti, guru, siswa, dan staf sekolah yang lain untuk menciptakan suatu kinerja sekolah yang lebih baik.

Penelitian ini dilaksanakan melalui 2 siklus yang ditempuh dengan prosedur sebagai berikut:

1. Tahap Perencanaan

a. Menyusun silabus dan rencana pembelajaran menulis puisi dengan media gambar;

b. Merancang skenario pembelajaran menulis puisi dengan media gambar;

c. Membantu siswa mempersiapkan gambar yang dikelompokkan menjadi beberapa tema (Keindahan Alam)

2. Tahap Pelaksanaan

a. Tahap ini dilakukan dalam pembelajaran satu siklus terdiri dari 1 kali pertemuan yaitu selama $2 \times 40$ menit;

b. Guru menyajikan media gambar dan menjelaskannya terlebih dahulu kepada siswa sebagai contoh;

c. Siswa diminta untuk mengamati dan memahami gambar pilihannya;

d. Siswa diminta untuk menuliskan puisi tentang keindahan alam dalam gambar tersebut dengan teknik kekaguman dan teknik foto berita/foto media dengan bantuan gambar dan imajinasi tentang keindahan alam;

3. Tahap Observasi

Tahap observasi dilakukan dengan mengamati proses pembelajaran, yang diarahkan pada poin-poin pedoman yang telah disiapkan peneliti;

4. Tahap Refleksi

Analisis dilakukan terhadap proses dan hasil pembelajaran. Berdasarkan hasil tersebut akan diperoleh kesimpulan, fase mana yang perlu diperbaiki dan fase mana yang telah memenuhi target. Halhal yang dilakukan pada tahap ini adalah:

(a) Mengevaluasi hasil observasi. (b) Menganalisis hasil pembelajaran (c).

Menyusun laporan.

Teknik pengumpulan data yang digunakan dalam penelitian ini yaitu observasi, wawancara, dan tes. Dalam penelitian ini, proses pembelajaran berhasil bila terdapat setidaknya $75 \%$ siswa menunjukkan perhatian dan konsentrasi selama apersepsi dan penyampaian materi, aktif selama 
pembelajaran berlangsung, dan mandiri dalam mengerjakan tugas menulis puisi, sedangkan keterampilan menulis puisi siswa diukur dari hasil puisi karya siswa yang telah memenuhi unsur-unsur tema, peristiwa, dan menyusun larik-larik puisi, dengan perolehan nilai minimal 70 sesuai KKM mata pelajaran Bahasa Indonesia di Kelas 7C SMP Negeri 2 Singkawang.

Adapun Indikator /kriteria penilaian puisi siswa pada tabel 1 adalah sebagai berikut :

1) Kesesuaian pilihan kata dengan tema puisi

2) Kesesuaian pilihan kata dengan peristiwa

3) Kesesuaian pilihan kata dalam lariklarik puisi.

Tabel 1

Indikator/Kriteria Penilaian Puisi Siswa

\begin{tabular}{|c|c|c|c|}
\hline No & Kriteria Penilaian & Nilai & $\begin{array}{c}\text { Nilai } \\
\text { Maksimal }\end{array}$ \\
\hline \multirow[t]{4}{*}{1} & $\begin{array}{l}\text { Kesesuaian pilihan } \\
\text { kata dengan Tema } \\
\text { Puisi }\end{array}$ & & 20 \\
\hline & $\begin{array}{ll}\text { a. } & \text { Sesuai } \\
\end{array}$ & $13-20$ & \\
\hline & b. Kurang sesuai & $7-12$ & \\
\hline & c. Tidak sesuai & $0-6$ & \\
\hline \multirow[t]{4}{*}{2} & $\begin{array}{ll}\text { Kesesuaian } & \text { pilihan } \\
\text { kata } & \text { dengan } \\
\text { Peristiwa } & \end{array}$ & & 20 \\
\hline & $\begin{array}{ll}\text { a. } & \text { Sesuai } \\
\end{array}$ & $13-20$ & \\
\hline & b. Kurang sesuai & $7-12$ & \\
\hline & c. Tidak sesuai & $0-6$ & \\
\hline \multirow[t]{5}{*}{3} & $\begin{array}{l}\text { Kesesuaian pilihan } \\
\text { kata dengan Larik- } \\
\text { Larik Puisi }\end{array}$ & & 60 \\
\hline & $\begin{array}{ll}\text { a. } & \text { Sesuai } \\
\end{array}$ & $41-60$ & \\
\hline & b. $\quad$ Kurang sesuai & $21-40$ & \\
\hline & $\begin{array}{ll}\text { c. } & \text { Tidak sesuai }\end{array}$ & $0-20$ & \\
\hline & $\begin{array}{l}\text { NILAI AKHIR = } \\
(1)+(2)+(3)\end{array}$ & & 100 \\
\hline
\end{tabular}

\section{PEMBAHASAN}

\section{Kondisi Awal Pelaksanaan Ke-giatan Pembelajaran di Kelas 7 C}

Sebelum melakukan penelitian terlebih dahulu peneliti melakukan survey awal/pra tindakan. Hal ini dilakukan untuk mengetahui kondisi awal pembelajaran di Kelas 7C. Selain itu, survey awal juga dilakukan untuk mencari informasi dan menemukan berbagai kendala yang dihadapi sekolah dalam proses pembelajaran Bahasa Indonesia. Wawancara dan observasi dengan guru dan siswa dilaksanakan pada tanggal 6 Pebruari 2017. Berdasarkan hasil kegiatan observasi pra tindakan di atas, dapat disampaikan hasil sebagai berikut:

1) Siswa pasif dan kurang fokus terhadap pembelajaran berlangsung;

2) Dari hasil pengamatan ini diperoleh data siswa yang aktif selama apersepsi sejumlah 15 orang siswa. Aktivitas siswa mengikuti pembelajaran diindikasikan dengan keberanian siswa mengajukan pertanyaan, menjawab dan berpendapat. Minat, motivasi dan perhatian siswa terhadap pembelajaran diindikasikan dengan perhatian siswa dan perilaku siswa yang tidak mengganggu jalannya pembelajaran;

3) Pembelajaran berlangsung secara konvensional;

4) Dalam pembelajaran, guru lebih dominan menggunakan metode ceramah. Pada awal pembelajaran terkesan komunikasi hanya berjalan satu arah, guru sebagai penyampai dan siswa sebagai penerima materi;

5) Media yang digunakan kurang menunjang;

6) Dalam pembelajaran ini guru hanya menggunakan media papan tulis, spidol dan materi penunjang dan buku acuan pelajaran Bahasa Indonesia dan Buku LKS;

7) Hasil pembelajaran siswa dalam keterampilan menulis puisi tentang keindahan alam kurang memuaskan. Dalam hal ini guru menugasi siswa untuk menulis puisi dengan tema bebas tentang keindahan alam. Berdasarkan hasil penilaian diperoleh nilai rata-rata kelas mencapai 67,03.

Hasil tes pra tindakan menunjukkan bahwa dari 34 orang siswa, sebanyak 8 siswa memperoleh nilai di bawah 70 dan 26 siswa 
memperoleh nilai di atas 70. Adapun indikator pencapaian kompetensi meliputi:

a. Mampu menentukan tema dalam penulisan puisi tentang keindahan alam

b. Mampu menetukan peristiwa dalam penulisan puisi

c. Mampu menyusun larik-larik puisi.

Data ini menunjukkan bahwa pembelajaran di kelas belum memenuhi batas ketuntasan yang ditetapkan. Dengan demikian pada kondisi awal pembelajaran ini, dikatakan belum mencapai tujuan yang diharapkan. Penyebabnya kemampuan siswa menulis surat pembaca yaitu kurang terjadi interaksi antara guru dan siswa atau sebaliknya karena hanya menggunakan metode ceramah. Kemudian siswa disuruh ke luar kelas untuk mengamati pemandangan, taman, gunung di sekitar halaman sekolah, untuk selanjutnya ditulis di kertas dan dituangkan ke dalam bentuk larik-larik puisi.

Hasil observasi terhadap pelaksanaan tindakan dapat dideskripsikan bahwa masih ada siswa yang kurang memperhatikan yang di ajarkan guru di kelas. Ketika guru menjelaskan pembelajaran kepada siswa banyak yang tidak memperhatikan karena metode yang digunakan masih kurang menarik, siswa terlihat kurang aktif terhadap pembelajaran yang disampaikan guru.

Berdasarkan data yang diperoleh pada kondisi awal menunjukkan belum terpenuhinya target yang diinginkan, yakni tercapainya kriteria ketuntasan minimal 70 . Hal ini dapat dijelaskan bahwa dari 34 siswa terdapat 8 orang yang nilainya di bawah 70 . Nilai masing-masing siswa tersebut diperoleh dari tiga indikator pencapaian kompetensi siswa dalam menulis puisi.

Pada kondisi awal, pencapaian kompetensi siswa di kelas 9D dalam menulis surat pembaca diperoleh skor rata-rata kelas per indikator sebagai berikut : (a) Indikator Tema dalam penulisan puisi, telah mencapai hasil sebesar 49,26\%; (b) Indikator peristiwa dalam menulis puisi sebesar 46,91\%. dan (c) Indikator menyusun larik-larik pada puisi sebesar $89,51 \%$.. Sedangkan nilai rata-rata kelas secara keseluruhan yaitu 67,03.

Grafik 1

Indikator Pencapaian Kompetensi Siswa dalam Menulis Puisi Pada Kondisi Awal

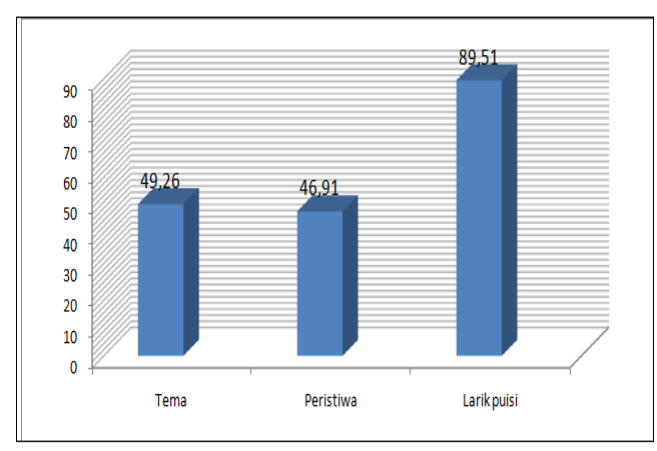

\section{Deskripsi Siklus I}

\section{a. Perencanaan Tindakan}

Kegiatan perencanaan ini dilakukan pada hari Senin tanggal 06 Februari 2017 di ruang kelas 7C SMP Negeri 2 Singkawang. Kegiatan perencanaan tindakan ini bertujuan untuk merencanakan pelaksanaan tindakan untuk meningkatkan kemampuan menulis puisi siswa dan juga untuk menumbuhkan ketertarikan siswa dalam kegiatan menulis, khususnya penulisan puisi. Peneliti sebagai guru bahasa Indonesia mendiskusikan rencana tindakan yang akan dilaksanakan. Pada kegiatan pelaksanaan tindakan siklus I ini hal-hal yang didiskusikan antara lain: (1) peneliti menyamakan persepsi dengan guru observer mengenai penelitian yang akan dilakukan, (2) peneliti mengusulkan digunakan media gambar pemandangan alam pilihan siswa dalam pembelajaran menulis puisi dan menjelaskan cara penggunaannya, (3) peneliti bersama guru mendiskusikan skenario pembelajaran menulis puisi dengan menggunakan media gambar pemandangan alam pilihan siswa, dan (4) menentukan jadwal pelaksanaan tindakan, yang disepakati bahwa siklus I dilaksanakan pada hari Senin, tanggal 06 Februari 2017.

b. Pelaksanaan Tindakan

Langkah-langkah yang dilakukan guru 
dalam siklus I ini adalah sebagai berikut.

1) Guru membuka pelajaran dengan mengucapkan salam dan mengecek kehadiran siswa;

2) Guru menyampaikan kompetensi yang akan dicapai;

3) Guru melakukan apersepsi dengan bertanya kepada beberapa siswa tentang pengalamannya dalam menyukai gambar pemandangan alam;

4) Guru memberikan materi tentang menulis puisi;

5) Guru memberikan penjelasan tentang teknik-teknik menulis puisi, khususnya teknik kekaguman dan teknik foto berita yang akan digunakan dalam pembelajaran menulis puisi dengan media gambar pemandangan alam kepada siswa;

6) Guru dan siswa berdiskusi tentang materi menulis puisi dengan media gambar pemandangan alam pilihan siswa;

7) Guru memberikan kesempatan kepada siswa untuk menanyakan hal- hal yang belum dipahami tentang materi menulis puisi;

8) Guru memperlihatkan beberapa gambar pemandangan alam dan memberikan sedikit penjelasan tentang pemandangan alam yang diperlihatkan;

9) Siswa mengeluarkan gambar pemandagan alam yang telah dipersiapkan dari rumah;

10)Siswa membuat puisi tentang pemandangan alam dengan teknik kekaguman dan teknik foto berita/foto media;

11) Guru menutup pelajaran.

\section{c. Observasi dan Interpretasi}

Kegiatan observasi dilaksanakan pada saat pembelajaran menulis puisi dengan media gambar keindahan alam berlangsung. Pengamatan (observasi) difokuskan pada situasi pelaksanaan pembelajaran, kegiatan yang dilakukan oleh guru, dan aktivitas yang dilakukan oleh siswa selama pembelajaran dengan media gambar pemandangan alam berlangsung. Dalam kegiatan penelitian ini, peneliti bertindak sebagai partisipan pasif yang melakukan pengamatan dari meja paling belakang yang memang tidak dipakai. Namun, sesekali peneliti juga berada di depan kelas untuk mengambil gambar sebagai dokumentasi.

\section{d. Analisis dan Refleksi Tindakan}

Tahap refleksi di mulai dengan menganalisis hasil tindakan pada siklus I. Setelah dilakukan tindakan berupa penggunaan media gambar pemandangan alam pilihan siswa pada pembelajaran menulis puisi, peneliti menemukan adanya peningkatan kemampuan menulis puisi pada kondisi awal ketuntasan klasikal siswa sebesar 67,03\%, sedangkan pada siklus I yaitu $79,76 \%$ yang dinyatakan tuntas berdasarkan KKM yang ditetapkan sebesar 70 .

Dari data tersebut ternyata sudah memenuhi harapan peneliti untuk mencapai target yang diinginkan yakni tercapainya nilai ketuntasan 70 , namun harus ditingkatkan. Nilai tersebut diperoleh dari tiga indikator pencapaian kompetensi siswa dalam menulis puisi.

Pencapaian kompetensi siswa di kelas 9D dalam menulis surat pembaca pada siklus I, diperoleh skor rata-rata kelas per indikator dapat dijelaskan sebagai berikut : (a) Pada indikator indikator Tema dalam penulisan puisi, telah mencapai hasil sebesar $74,71 \%$. (b) Pada Pada indikator peristiwa dalam menulis puisi sebesar $76,76 \%$, dan (c) Pada indikator menyusun larik-larik pada puisi sebesar $94,17 \%$. Sedangkan nilai rata-rata kelas secara keseluruhan yaitu 79,76, mengalami peningkatan dari hasil belajar sebelumnya yakni 67,03 . Hal ini bisa dilihat pada grafik I (satu).

Grafik 2

Indikator Pencapaian Kompetensi Siswa dalam Menulis Puisi pada Siklus I

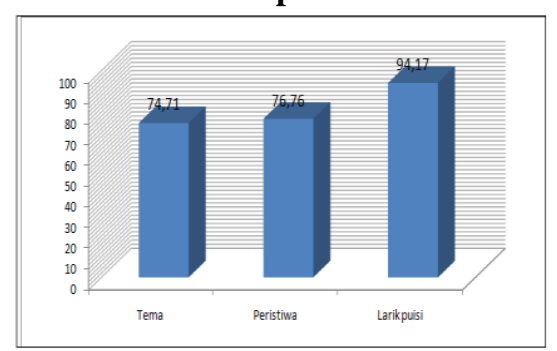




\section{Deskripsi Siklus II}

\section{a. Perencanaan Tindakan}

Berdasarkan hasil analisis dan refleksi pada siklus I, guru dan peneliti sepakat bahwa siklus II perlu dilakukan untuk memperbaiki kekurangan pada siklus I serta untuk lebih memaksimalkan kemampuan menulis puisi siswa kelas 7C SMP Negeri 2 Singkawang. Persiapan dan perencanaan tindakan untuk siklus II dilakukan pada hari Kamis, 09 Februari 2017 di ruang Kelas 7C SMP Negeri 2 Singkawang.

\section{b. Pelaksanaan Tindakan}

Langkah-langkah yang dilakukan guru dalam siklus II ini adalah sebagai berikut.

1) Guru membuka pelajaran dengan mengucapkan salam dan mengecek kehadiran siswa.

2) Guru mengevaluasi hasil kerja siswa pada pertemuan sebelumnya.

Dari evaluasi diketahui bahwa puisi karangan siswa pada siklus I masih banyak yang belum memperhatikan unsur-unsur puisi yang meliputi diksi, pengimajian, bahasa kiasan (majas), dan rima.

3) Guru memberikan pendalaman materi tentang unsur-unsur puisi, khususnya tentang diksi, pengimajian, bahasa kiasan (majas), dan rima.

4) Guru memberikan kesempatan kepada siswa untuk menanyakan hal- hal yang belum dipahami tentang materi menulis puisi.

5) Siswa membuat membuat puisi tentang pemandangan alam dengan teknik kekaguman

6) Guru melakukan refleksi dan menutup pelajaran.

c. Observasi dan Interpretasi

Sebelum membuat puisi tentang pemandangan alam, terlebih dahulu siswa diminta menganalisis unsur-unsur yang terdapat dalam puisi yang telah dicontohkan oleh guru. Guru bertanya tentang gaya bahasa, rima, diksi, dan imaji yang terdapat dalam puisi tersebut.

Pada saat membuat puisi, guru kembali mengingatkan siswa tentang langkahlangkah yang digunakan untuk membuat puisi tentang pemandangan alam ini dengan teknik kekaguman. Terlebih dahulu siswa diminta menempelkan gambar pemandangan alam pada kertas yang telah disediakan. Kemudian siswa diminta mengamati gambar pemandangan alam dengan seksama sambil membayangkan keindahan alam tersebut. Siswa dapat berimajinasi tentang keindahan pemandangan alam tersebut. Siswa diminta fokus pada gambar dan pada hal-hal yang berkaitan dengan pemandangan alam tersebut. Diharapkan dari situ akan dapat memunculkan inspirasi menulis puisi bagi siswa. Setelah siswa dapat berimajinasi dengan baik serta memperoleh gambaran tentang pemandangan alam, siswa diminta menuliskan pengalaman batin dan hal- hal yang dirasakan dalam larik-larik puisi. Kali ini guru menambahkan agar puisi siswa dibuat dalam larik-larik yang sederhana terlebih dahulu, baru kemudian kata-kata yang awalnya sederhana tersebut dicari padanan kata lainnya yang lebih indah atau mengandung nilai estetis.

\section{d. Analisis dan Refleksi}

Tahap refleksi di mulai dengan menganalisis hasil tindakan pada siklus II. Setelah dilakukan tindakan berupa penggunaan media gambar pemandangan alam pilihan siswa pada pembelajaran menulis puisi, peneliti menemukan adanya peningkatan kemampuan menulis puisi pada siswa sebesar 91,97\%.

Secara umum, pembelajaran menulis puisi siklus II ini berlangsung jauh lebih baik dari pada pembelajaran menulis puisi pada siklus sebelumnya. Siswa lebih antusias dan bersemangat mengikuti pelajaran. Sudah banyak siswa yang lebih aktif selama pembelajaran berlangsung. Siswa dengan inisiatif mereka sendiri juga sudah mau mengacungkan jari untuk mengemukakan pendapat atau menjawab pertanyaan dari 
guru, padahal pada siklus I siswa masih tampak malu-malu untuk mengemukakan pendapat, bertanya, atau menjawab pertanyaan yang diberikan oleh guru. Selain itu, sudah banyak siswa yang mampu mengemukakan ide, gagasan dan pengalaman batinnya dalam bentuk puisi. Puisi hasil karya siswa juga sudah banyak yang memenuhi unsur- unsur yang diharapkan ada dalam sebuah puisi.

Hasil belajar siswa pada siklus II dengan menggunakan media gambar dalam menulis puisi mengalami peningkatan dari hasil belajar sebelumnya. Nilai rata-rata kelas secara keseluruhan yaitu 91,97, mengalami peningkatan dari hasil belajar sebelumnya yakni 79,76 (Siklus I) dan 67,03 (Kondisi awal). Siswa yang tuntas belajar dengan kriteria ketuntasan minimal (KKM) 70 sebanyak 34 orang yaitu $100 \%$.

Nilai tersebut diperoleh dari tiga indikator pencapaian kompetensi siswa dalam menulis puisi. Berdasarkan indikator keberhasilan, pencapaian kompetensi siswa di kelas 7C dalam menulis puisi yang dicapai pada siklus II, diperoleh skor rata-rata kelas per indikator sebagai berikut: (a) pada indikator indikator Tema dalam penulisan puisi, telah mencapai hasil sebesar $86,47 \%$. (b) pada indikator peristiwa dalam menulis puisi sebesar 89,71 $\%$; dan (c) pada indikator menyusun lariklarik pada puisi sebesar 94,56 \%. Hal ini bisa dilihat pada grafik 3 (tiga).

Grafik 3

Indikator Pencapaian Kompetensi Siswa dalam Menulis Puisi Dengan Media Gambar Pada Siklus II

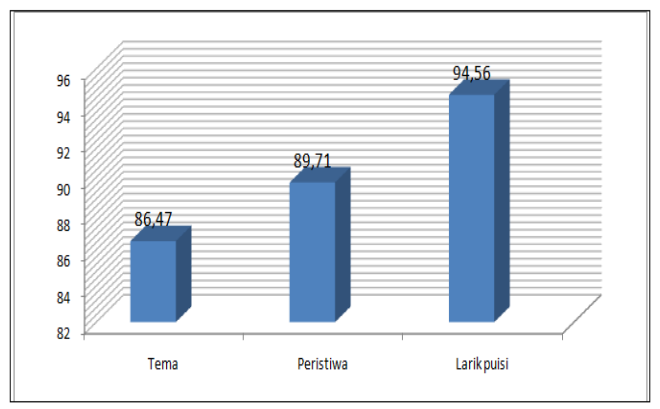

Pembahasan Hasil Penelitian
Langkah awal sebelum dilak-sanakannya tindakan pada siklus I, guru dan peneliti menyusun Rencana Pelaksanaan Pembelajaran (RPP). Pada siklus I ini siswa diberikan materi tentang menulis puisi yang meliputi pengertian, unsur- unsur, dan teknik-teknik membuat puisi. Kemudian diminta untuk menulis puisi tentang keindahan alam dengan bantuan media gambar masing- masing siswa dangan teknik kekaguman. Awalnya siswa diminta menempelkan gambar tersebut pada kertas yang telah disediakan. Langkah berikutnya siswa dipersilahkan mengamati gambar pemandangan alam dengan seksama sambil membayangkan kehidupan dan pengalaman tersebut. Siswa diminta seolah-olah begitu dekat dengan alam tersebut dan dapat merasakan berada di lingkungan tersebut. Setelah siswa dapat berimajinasi dengan baik serta memperoleh gambaran tentang pemandagnan alam siswa diminta menuliskan pengalaman batin dan hal-hal yang dirasakan dalam larik-larik puisi dengan memperhatikan kekuatan bunyi dan permainan kata. Pada saat membuat puisi, sebagian besar siswa tampak membolak-balik buku paket dan LKS Bahasa Indonesia mereka. Ada juga siswa yang bertanya kepada temannya atau melihat hasil karya temannya. Meskipun demikian, beberapa siswa lain sudah bisa menulis puisi tanpa bantuan buku, teman, atau gurunya. Setelah dilakukan evaluasi, ternyata siklus I memang masih mengalami banyak kekurangan, diantaranya: kondisi kelas yang kurang kondusif, banyak siswa yang belum aktif dalam kegiatan pembelajaran, serta belum adanya refleksi di akhir pembelajaran. Selain itu ketika menulis puisi, banyak siswa yang belum begitu memperhatikan unsurunsur yang seharusnya ada dalam sebuah puisi. Kekurangan-kekurangan yang terdapat pada siklus I ini selanjutnya akan diperbaiki pada tindakan siklus II.

Pada siklus II guru memberikan pendalaman materi menulis puisi dan mengajak siswa untuk melihat dan 
mendiskusikan kelebihan dan kekurangan puisi yang telah mereka buat pada siklus sebelumnya.

Ketika guru memberikan materi, sudah banyak siswa yang memperhatikan dengan seksama sambil mencatat dan menjawab pertanyaan yang beberapa kali diajukan oleh guru.

Ketika diberi tugas menulis puisi sebagian besar siswa sudah bisa dan siap membuat puisi tentang pemandangan alam, tetapi ada juga beberapa siswa yang masih belum menemukan ide dan hanya diam termangu sambil melihat kegiatan teman lainnya.

Langkah-langkah yang diterapkan dalam pembelajaran menulis puisi siklus II ini hampir sama dengan langkah-langkah menulis puisi pada siklus I.

Terlebih dahulu siswa diminta menempelkan gambar pemandangan alam pada kertas yang telah disediakan. Selanjutnya, siswa diminta mengamati gambar pemandangan alam pilihan siswa dengan seksama.

Siswa diminta fokus pada gambar dan pada hal-hal yang berkaitan dengan pemandangan alam tersebut. Diharapkan dari situ akan dapat memunculkan inspirasi menulis puisi bagi siswa. Setelah siswa dapat berimajinasi dengan baik memperoleh serta gambaran tentang pemandangan alam pilihannya, siswa diminta menuliskan pengalaman batin dan hal-hal yang dirasakan dalam larik-larik puisi.

Hasil akhir berupa penilaian kemampuan menulis puisi tentang keindahan alam diperoleh nilai yang melebihi target peneliti.

Dengan demikian hasil yang diperoleh sudah sesuai dengan hipotesis tindakan yang diajukan yaitu melalui Media Gambar dan sesuai dengan psikologi siswa kelas 7C serta diskusi dengan teman kelompoknya sehingga dapat meningkatkan kemampuan menulis puisi tentang keindahan alam.
Secara keseluruhan analisis data baik siklus I maupun siklus II adalah sebagai berikut :

Grafik 4

Indikator Pencapaian Kompetensi Siswa Menulis Puisi Keindahan Alam dengan Media Gambar Pada kondisi awal, Siklus I dan Siklus II

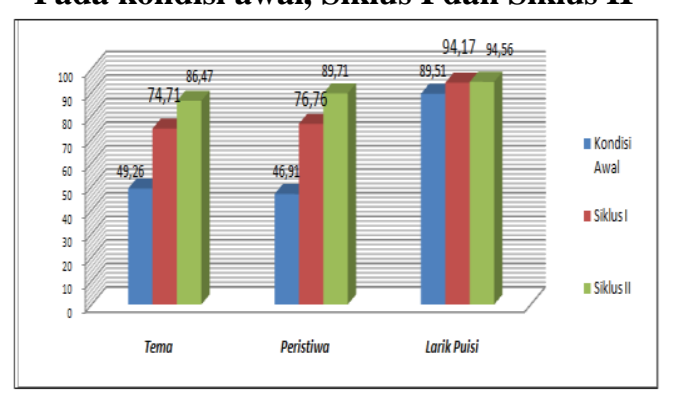

Setelah diadakan tindakan pada siklus II maka beberapa aspek pada siklus I yang masih belum memenuhi harapan peneliti ternyata pada siklus II sudah memenuhi harapan dan semua aspek mengalami peningkatan. Kondisi ini dapat digambarkan dalam tabel 2 di bawah ini :

Tabel 2

Peningkatan Persentase Indikator Pencapaian Kompetensi Pada

Kondisi Awal, Siklus I Dan Siklus II

\begin{tabular}{|l|c|c|c|c|}
\hline \multirow{2}{*}{ Tindakan } & \multicolumn{3}{|c|}{ Indikator Pencapaian Kompetensi } & \multirow{2}{*}{ Nilai } \\
\cline { 2 - 4 } & Tema & Peristiwa & $\begin{array}{c}\text { Larik } \\
\text { Puisi }\end{array}$ & \\
\hline $\begin{array}{l}\text { KONDISI } \\
\text { AWAL }\end{array}$ & 49,26 & 46,91 & 89,51 & 67,03 \\
\hline SIKLUS I & 74,71 & 76,76 & 94,17 & 79,76 \\
\hline SIKLUS II & 86,47 & 89,71 & 94,56 & 91,97 \\
\hline $\begin{array}{l}\text { Peningkatan } \\
\begin{array}{l}\text { Pada siklus I } \\
\text { dan II }\end{array}\end{array}$ & 11,76 & 12,95 & 0,39 & 12,21 \\
\hline
\end{tabular}

Berdasarkan tabel diatas terlihat bahwa terjadi peningkatan kompetensi siswa dalam menulis puisi pada kondisi awal, siklus I dan siklus II.

\section{PENUTUP}

\section{Simpulan}

Penggunaan media gambar dalam pembelajaran menulis puisi pada siswa kelas 7C SMP Negeri 2 Singkawang, mampu meningkatkan proses pembelajaran 
menulis puisi. Hal ini dapat diketahui dari adanya peningkatan indikator-indikator yang telah ditetapkan. Persentase perhatian dan konsentrasi siswa selama apersepsi dan pada saat pembelajaran menulis puisi dengan media gambar berlangsung terus mengalami peningkatan.Media gambar dapat meningkatkan keterampilan menulis puisi. Hal ini dapat diketahui dari adanya peningkatan persentase nilai menulis siswa setiap siklusnya.

\section{Saran}

Bagi Guru, dapat mengenalkan media gambar terhadap rekan sejawatnya, sehingga guru yang lain juga dapat mempraktikkan media gambar dalam pembelajaran menulis puisi. Pada saat memilih media, metode dan sumber belajar yang tepat sesuai dengan materi yang akan diajarkan untuk mendapatkan hasil yang maksimal. Guru dapat mencari media pembelajaran lain yang lebih inovatif dan kreatif untuk meningkatkan proses pembelajaran dan hasil pembelajaran serta agar siswa tidak mengalami kejenuhan.

Bagi Siswa, sebaiknya lebih kritis dan terbuka terhadap hal-hal baru yang mereka peroleh sehingga mampu menunjang proses dan hasil belajar mereka di sekolah. Selanjutnya siswa lebih aktif dan berani selama proses pembelajaran berlangsung.

Bagi Sekolah, sebaiknya semakin giat memberikan motivasi kepada guru untuk terus mengembangkan diri dengan melakukan banyak penelitian. Hal ini bertujuan untuk meningkatkan kualitas guru dan keterampilan mengajar guru. Sekolah hendaknya memberikan kesempatan dan dukungan kepada pendidik untuk menggunakan media pembelajaran yang lebih bervariasi.

\section{DAFTAR PUSTAKA}

Alamsyah, Muhammad. 2015. Pengertian Media Gambar. (http://dunia dalam pendidikan.blogspot.co.id/2015/10/pen gerti,an-media-gambar.html) diakses 13 Mei 2017.
Arikunto, Suharsimi. 2006. Prosedur Penelitian Suatu Pendekatan Praktik. Jakarta: Rineka Cipta.

Arsyad, Azhar. 2007. Media Pembelajaran. Jakarta: PT. Raja Grafindo Persada.

Daryanto. 2011. Media Pembelajaran. Bandung: PT Sarana Tutorial Nurani Sejahtera.

Depdiknas. 2005. Materi Pelatihan Terintegrasi, Bahasa dan Sastra Indonesia, Buku 3. Jakarta: Departemen Pendidikan Nasional, Direktorat Jenderal Pendidikan Dasar dan Menengah, Direktorat Pendidikan Lanjutan Pertama.

Sanaky, Hujair AH. 2009. Media Pembelajaran. Yogyakarta: Safiria Insania Press.

Maharani, Pramita Dewi. 2012. Peningkatan Keterampilan Menulis Puisi Dengan Media Gambar Pada Siswa Kelas VII B Mts Muhammadiyah 6 Karanganyar Tahun Ajaran 2011/2012. Skripsi. Jurusan Pendidikan Bahasa Sastra Indonesia dan Daerah, Fakultas Keguruan dan Ilmu Pendidikan, Universitas Muhammadiyah, Surakarta. Peraturan Menteri Pendidikan Nasional Nomor 22 Tahun 2006 tanggal 23 Mei 2006 tentang Standar Isi Untuk Satuan Pendidikan Dan Menengah

Prasetyo, Budi. 2007. "Peningkatan Pembelajaran Menulis Puisi dengan Strategi Pikir Plus" Jurnal Pendidikan Inovatif, volume 2, No.2, edisi Maret 2007 hal 57-63.

Rahadi, Aristo. 2003. Media Pembelajaran. Jakarta: Dirjen Dikti Depdikbud.

Sadiman, Arief S. 2001. Penggunaan Media dalam Pembelajaran, Jakarta: Rineka Cipta.

Sadiman, Arief S, dkk. 2011. Media Pendidikan, Jakarta: Raja Grafindo.

Setiyaningsih, Ika. 2015. Pegangan Guru Bahasa Indonesia Kelas VII Semester

2. Klaten: PT Intan Pariwara.

Sudibyo, Arief. 2008. Sekilas Tentang Menulis Puisi. ( http://republikpuisi- 
reeve. blogspot.com/2008/06/sekilastentang-menulis-puisi.html) diakses 22 Februari 2012.

Sudjana, Nana dan Rivai, Ahmad. 2007. Media Pengajaran. Bandung: Sinar Baru Algensindo.

Sukidin, Basrowi, Suranto. 2002. Manajemen Penelitian Tindakan Kelas. Jakarta: Insan Cendikia.

Suryana, Nana. 2013. Upaya Meningkatkan Kemampuan Menulis Puisi Melalui Pembelajaran Menulis Puisi Dengan Menggunakan Media Gambar. (http://bindokotasmgmp.blogspot.co.id/ 2013/01/laporan-ptk-nana-smpn.html) diakses 13 Mei 2017.

Suyatno. 2004. Teknik Pembelajaran Bahasa dan Sastra. Surabaya: SIC.
Syarif, Elina. Dkk. 2009. Pembelajaran Menulis, Jakarta: PPPPTK Bahasa, Dirjen PMPTK, Depdiknas.

Tarigan, Henry, Guntur. 2008. Menulis Sebagai Suatu Keterampilan Berbahasa, Bandung: Angkasa.

Wiriaadmadja, Rochiati. 2005. Metode Penelitian Tindakan Kelas Untuk Meningkatkan Kinerja Guru Dan Dosen. Bandung: Rosda Karya.

Yuliyanto. 2009. Peningkatan Kemampuan Menulis Puisi dengan Media Gambar Karikatur melalui Teknik Pancingan Kata Kunci Siswa Kelas VIII F SMP Negeri 13 Semarang Tahun Pelajaran 2008/2009. Skripsi. Jurusan Bahasa dan Sastra Indonesia. Fakultas Bahasa dan Seni, Universitas Negeri Semarang. 
Totobuang, Vol.5, No. 2, Desember 2017: 199—213 